\title{
Formation of a 1,4-Diamino-2,3-disila-1,3-butadiene Derivative
}

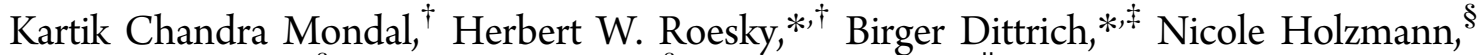 \\ Markus Hermann, ${ }^{\S}$ Gernot Frenking, ${ }^{*}, \S$ and Alke Meents $\|$ \\ ${ }^{\dagger}$ Institut für Anorganische Chemie, Georg-August-Universität, Tammannstraße 4, 37077 Göttingen, Germany \\ ${ }^{\ddagger}$ Martin-Luther-King-Platz 6, Raum AC 15c (Erdgeschoss), 20146 Hamburg, Germany \\ ${ }^{\S}$ Fachbereich Chemie, Philipps-Universität Marburg, Hans-Meerwein-Straße, 35032 Marburg, Germany \\ "Deutsches Elektronen-Synchrotron DESY, Notkestraße 85, 22607 Hamburg, Germany
}

Supporting Information

ABSTRACT: A 1,4-diamino-2,3-disila-1,3-butadiene derivative of composition $\left(\mathrm{Me}_{2} \text {-cAAC }\right)_{2}\left(\mathrm{Si}_{2} \mathrm{Cl}_{2}\right)\left(\mathrm{Me}_{2}\right.$-cAAC $\left.=: \mathrm{C}\left(\mathrm{CMe}_{2}\right)_{2}\left(\mathrm{CH}_{2}\right) \mathrm{N}-2,6-i \mathrm{Pr}_{2} \mathrm{C}_{6} \mathrm{H}_{3}\right)$ was synthesized by reduction of the $\mathrm{Me}_{2}-\mathrm{cAAC}: \mathrm{SiCl}_{4}$ adduct with $\mathrm{KC}_{8}$. This compound is stable at $0{ }^{\circ} \mathrm{C}$ for 3 months in an inert atmosphere. Theoretical studies reveal that the silicon atoms exhibit pyramidal coordination, where the $\mathrm{Cl}-\mathrm{Si}-$ $\mathrm{Si}-\mathrm{Cl}$ dihedral angle is twisted by $43.3^{\circ}\left(\right.$ calcd $\left.45.9^{\circ}\right)$. The two silicon-carbon bonds are intermediates between single and double $\mathrm{Si}-\mathrm{C}$ bonds due to twisting of the $\mathrm{C}-\mathrm{Si}-\mathrm{Si}-\mathrm{C}$ dihedral angle $\left(163 \cdot 6^{\circ}\right)$.

Silicon chemistry, with $\mathrm{Si}$ as the sister element of carbon, has $\checkmark$ seen a number of exciting developments in recent years. Among the unsaturated compounds the disilynes $\mathrm{RSi} \equiv \mathrm{SiR}$ of Sekiguchi et al. and Wiberg et al. were highlights in this field, ${ }^{1}$ whereas a compound with a $\mathrm{C} \equiv \mathrm{Si}$ triple bond was characterized by Baceiredo et al., ${ }^{2}$ although the latter is only stable up to $-30{ }^{\circ} \mathrm{C}$. Apeloig, Schwarz, and co-workers ${ }^{3}$ characterized small silynes $\mathrm{HC} \equiv \mathrm{SiX}$ in the gas phase. The first compounds with $\mathrm{Si}=\mathrm{C}$ and $\mathrm{Si}=\mathrm{Si}$ double bonds were already reported 30 years ago, ${ }^{4}$ followed by a hexaaryltetrasilabuta-1,3diene in 1997.5 In recent years, $\mathrm{N}$-heterocyclic carbenes (NHC) and cyclic alkyl(amino) carbenes (cAAC) have been used for the stabilization of silylenes. ${ }^{6,7}$ In the former, the carbene carbon atom is bound to two $\sigma$-withdrawing and $\pi$ donating $\mathrm{N}$-atoms. However, in the case of cAAC one of the $\sigma$ withdrawing and $\pi$-donating $\mathrm{N}$-atoms is replaced by one $\sigma$ donating quaternary $\mathrm{C}$-atom. Thus, the cAAC becomes more nucleophilic but also more electrophilic when compared with that of NHC. ${ }^{8}$ Thus, the electronic properties of analogous compounds of NHC and cAAC may change dramatically. For example, Robinson et al. have shown ${ }^{9 a}$ that NHC:-stabilized $\mathrm{P}_{2}$ allotrope can have two canonical forms; NHC: $\rightarrow \mathrm{P}-\mathrm{P} \leftarrow: \mathrm{CHN}$ and $\mathrm{NHC}=\mathrm{P}-\mathrm{P}=\mathrm{CHN}$. The former conformer ${ }^{9 \mathrm{a}}$ was stated as the predominant product based on the chemical shift values of ${ }^{31} \mathrm{P}$ NMR, while the latter one ${ }^{9 b}$ was shown to be the only conformer for the cAAC: analogue. ${ }^{9}$ Furthermore, it was observed that two radical centers could be easily generated just next to the $\mathrm{SiCl}_{2}$ unit by replacing one $\mathrm{NHC}$ of $\mathrm{NHC}: \mathrm{SiCl}_{2}$ by two cAAC due to their better $\pi$-accepting ability and the lower singlet-triplet gap than that of $\mathrm{NHC}^{7}$ This explains the dramatic change from a donor-acceptor bond in $\mathrm{NHC} \rightarrow \mathrm{SiCl}_{2}$ to electron-sharing bonds in $\mathrm{cAAC}-\mathrm{SiCl}_{2}-\mathrm{cAAC}$, with a singlet biradical spin ground state. ${ }^{7 \mathrm{a}}$

This chemical behavior of cAAC has no precedence with $\mathrm{NHC}$ which is due to the small HOMO-LUMO gap of the former. However, in common both $\mathrm{cAAC}^{10}$ and $\mathrm{NHC}$ form a stable adduct with $\mathrm{SiCl}_{4}$. The $\mathrm{NHC}: \mathrm{SiCl}_{4}$ adduct was reduced to a base-stabilized singlet bis-silylene $(\mathrm{NHC:Si}(:) \mathrm{Cl})_{2}(\mathrm{~A})$ and $\mathrm{NHC}: \mathrm{Si}=\mathrm{Si}$ :NHC (B) utilizing $\mathrm{KC}_{8}$ as a reducing reagent. ${ }^{11}$ In a recent review, ${ }^{12}$ Bertrand et al. mentioned that an analogue of Robinson's B with cAAC carbene might be expected to form a biradical. To investigate this further we targeted the synthesis of the cAAC analogue of $\mathbf{A}$.

The three-electron reduction of $\mathrm{Me}_{2}$-cAAC: $\mathrm{SiCl}_{4}(\mathbf{1})^{10}$ with $\mathrm{KC}_{8}$ in a molar ratio of $1: 3$ in THF resulted in $\left(\mathrm{Me}_{2}-\right.$ cAAC $)_{2}\left(\mathrm{Si}_{2} \mathrm{Cl}_{2}\right)(2)$. The reaction proceeds already at $-78{ }^{\circ} \mathrm{C}$; it took $30 \mathrm{~min}$ to obtain a green solution (Supporting Information). The temperature was slowly raised, and stirring was continued at room temperature for $3 \mathrm{~h}$ to obtain a red solution of $\left(\mathrm{Me}_{2}-\mathrm{cAAC}\right)_{2}\left(\mathrm{Si}_{2} \mathrm{Cl}_{2}\right)$ (2) (Scheme 1). Compound

Scheme 1. Synthesis of Compound 2 from 1 under $\mathrm{KC}_{8}$ Reduction

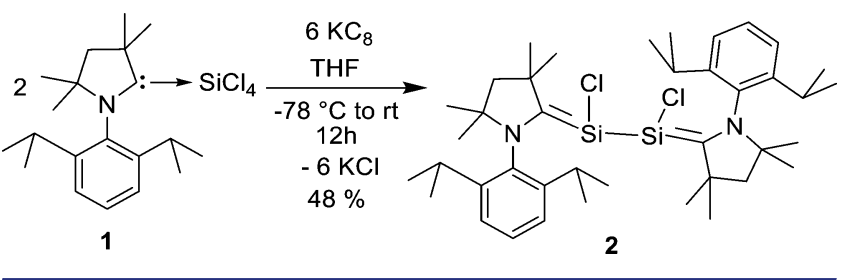

2 was extracted with $n$-hexane and crystallized as a red solid in $48 \%$ yield. The X-ray single-crystal structure analysis of 2 revealed a unprecedented formation of a $\mathrm{C}=\mathrm{Si}-\mathrm{Si}=\mathrm{C}$ chain (Scheme 1) instead of the monomeric silylene radical of composition ( $\mathrm{Me}_{2}$-cAAC.)-Si(:)Cl. To the best of our knowledge, a mixed carbon and silicon-centered chain of a stable and isolable 1,4-diamino-2,3-disila-1,3-butadiene has not been reported before.

Compounds $\mathbf{1}$ and $\mathbf{2}$ are isolated and colorless and rose-red solid, respectively. Compound $\mathbf{2}$ is soluble in toluene, benzene, $n$-hexane, and THF, whereas $\mathbf{1}$ is only soluble in THF due to its

Received: July 15, 2013

Published: October 10, 2013 
zwitterionic nature. Compound $\mathbf{2}$ is stable in an inert atmosphere for 3 months at -32 to $0{ }^{\circ} \mathrm{C}$, but it slowly decomposes to a colorless solid after one week upon storage at room temperature and loses its color completely in 3-4 weeks.

Compound 2 decomposes above $109^{\circ} \mathrm{C}$ and turns to darker red, above $128{ }^{\circ} \mathrm{C}$ adopts a brown red and finally melts to form a black brown liquid at $200{ }^{\circ} \mathrm{C}$. Compound 2 is stable in solution in an inert atmosphere but immediately hydrolyzes to the $\mathrm{Me}_{2}$-cAAC: $\mathrm{H}^{+} \mathrm{Cl}^{-}$salt upon exposure to air.

The UV-Vis spectrum of compound 2 was recorded in $n$ hexane, which exhibited absorption bands at $615,526,438,349$, $254 \mathrm{~nm}$ (Supporting Information). The biradical $\left(\mathrm{Me}_{2}-\right.$ cAAC $)_{2} \mathrm{SiCl}_{2}$ and the biradicaloid siladicarbene $\left(\mathrm{Me}_{2} \text {-cAAC }\right)_{2} \mathrm{Si}$ show absorptions at higher values $\left(569,{ }^{7 \mathrm{a}} 569\right.$ and $\left.611 \mathrm{~nm}\right){ }^{7 \mathrm{~b}}$ The ${ }^{29} \mathrm{Si}$ NMR spectrum of 2 exhibits a resonance at $\delta=+25.62$ ppm which is downfield shifted with respect to that of the precursor 1 ( $\delta=-103.5 \mathrm{ppm},{ }^{10}$ Supporting Information) but upfield shifted $(\delta=+38.4 \mathrm{ppm})$ when compared with (NHC:Si(:)Cl $)_{2}(\mathbf{A}) .^{11}$

Compound $\mathbf{2}$ crystallizes in the triclinic space group $P \overline{1}$. The asymmetric unit contains two molecules of 2 . Each of the silicon atoms adopts a distorted trigonal pyramidal geometry (Figure 1). It is well-known that the $\mathrm{Si}-\mathrm{Cl}$ bond distances

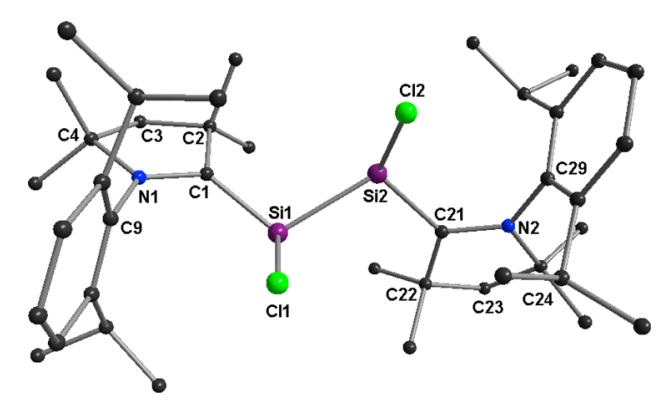

Figure 1. Molecular structure of compound 2. H-atoms and isopropyl groups are omitted for clarity. Selected experimental (calculated at BP86/TZVPP for the singlet state) bond lengths (pm) and angles (deg) (as averages of two independent molecules): Si1-C1/Si2-C21 182.3(3)/182.6(3) (185.9), Si1-Cl1/Si2-Cl2 210.27(18)/ 209.10(13) (214.6/214.7), C1-N1/C21-N2 133.6(3)/133.7(2) (136.0), Sil-Si2 230.58(13) (236.8), N1-C9/N2-C29 143.8(2)/ $143.7(2)$ (145.1), N1-C1-C2/N2-C21-C22 107.85(17)/ 107.95(17) (108.1), C1-Si1-Si2/C21-Si1-Si2 110.40(8)/ $110.85(8)(108.0 / 108.1), \mathrm{C} 1-\mathrm{Si} 1-\mathrm{Cl} 1 / \mathrm{C} 21-\mathrm{Si} 2-\mathrm{Cl} 2110.95(8) /$ 110.85(8) (111.2/111.4), Cl1-Si1-Si2/Cl2-Si2-Si1 106.62(4)/ 107.30(6) (107.9/108.0), Cl1-Si1-Si2-Cl2 43.31 (45.9), C1-Si1Si2-C21 163.56 (165.0).

depend on the coordination number and formal oxidation state of the silicon atom. The $\mathrm{Si}-\mathrm{C} 1$ bond distances are in the range of 205.81(9) to $219.64(10) \mathrm{pm}$ for the precursor (1) ${ }^{10}$ and 203.96(4) to 206.48(4) $\mathrm{pm}$ for the biradical $\left(\mathrm{Me}_{2}-\right.$ cAAC. ${ }_{2} \mathrm{SiCl}_{2}{ }^{7 \mathrm{a}}$ The experimentally observed $\mathrm{Si}-\mathrm{Cl}$ and $\mathrm{Si}-$ $\mathrm{C}_{\text {carbene }}$ bond distances in 2 are 209.10(13)-210.27(18) and 182.3(3)-182.6(3) pm. The $\mathrm{Si}-\mathrm{C}_{\text {carbene }}$ bond length is 194.4(2) pm in the precursor $1^{10}$

It is noteworthy that the $\mathrm{Si}-\mathrm{C}$ distances in $\mathbf{2}$ are longer than $\mathrm{Si}=\mathrm{C}$ double bonds $(170.2-177.5 \mathrm{pm}){ }^{13}$ The longer siliconcarbon bonds in 2 are likely caused by the twisted $\mathrm{C}-\mathrm{Si}-\mathrm{Si}-\mathrm{C}$ unit and particularly by the pyramidal coordination at the silicon atoms. This becomes obvious from the dihedral angle $\mathrm{Cl} 1-\mathrm{Si} 1-\mathrm{Si} 2-\mathrm{Cl} 2$ of $43.31^{\circ}$ which deviates significantly from a planar arrangement. Two of the silicon-carbon bonds are intermediates between single and double $\mathrm{Si}-\mathrm{C}$ bonds which are $10 \mathrm{pm}$ shorter than the values $(193.9(6)-192.9(7) \mathrm{pm})$ reported for $(\mathrm{NHC}: \mathrm{Si}(:) \mathrm{Cl})_{2}(\mathrm{~A}) .{ }^{11}$ The $\mathrm{Si}-\mathrm{Si}$ bond distance in 2 is $230.58(13) \mathrm{pm}$ and therefore $\sim 9 \mathrm{pm}$ shorter than the $\mathrm{Si}-\mathrm{Si}$ single bond $(239.3(3) \mathrm{pm})$ of $(\mathrm{NHC}: \mathrm{Si}(:) \mathrm{Cl})_{2}$ (A) but $\sim 7 \mathrm{pm}$ longer than the $\mathrm{Si}=\mathrm{Si}$ double bond length of NHC:Si=Si:NHC (B). ${ }^{11}$ The above-mentioned comparison suggests that there might be some additional bonding between the two silicon atoms. The $\mathrm{C}_{\text {carbene }}-\mathrm{N}$ bond lengths of $\mathbf{2}$ are slightly different (133.6(3)-133.7(2) pm) and are a little shorter than in the biradical $\left(\mathrm{Me}_{2} \text {-cAAC }\right)_{2} \mathrm{SiCl}_{2}{ }^{\mathrm{7a}}(139.94(19)$ $\mathrm{pm})$, however, longer $(\sim 3 \mathrm{pm})$ than that $(130.6(3) \mathrm{pm})$ observed for the zwitterionic precursor 1 . Moreover, the $\mathrm{N}-$ $\mathrm{C}_{\text {carbene }}-\mathrm{C}$ angles in $2\left(107.85(17)-107.95(17)^{\circ}\right)$ are slightly sharper when compared with that of $1\left(111.15(13)^{\circ}\right)$. The C$\mathrm{Si}-\mathrm{Cl}$ bond angles of 2 are in the range of $110.95(8)-$ $110.85(8)^{\circ}$ which are more acute $\left(\sim 9-10^{\circ}\right)$ than those $\left(100.7(2)-101.2(2)^{\circ}\right)$ of $(\mathrm{NHC}: \mathrm{Si}(:) \mathrm{Cl})_{2}(\mathbf{A}) .^{11}$ The Cl-Si$\mathrm{Si}$ bond angles in 2 are in the range of $106.62(4)-107.30(6)^{\circ}$ which are close to the values $\left(107.96(11)-108.75(11)^{\circ}\right)$ reported for $\mathrm{A}$. The $\mathrm{C}-\mathrm{Si}-\mathrm{Si}$ bond angles in $\mathbf{2}$ are $110.40(8)-110.85(8)^{\circ}$ which are wider by $\sim 9-11^{\circ}$ than those of $\mathbf{A}\left(98.76(19)-98.7(2)^{\circ}\right) .^{11}$ The sum of the bond angles around $\mathrm{Si} 1$ and $\mathrm{Si} 2$ in 2 is $327.96^{\circ}$ and $325.34^{\circ}$, respectively. The distances from each of the silicon atoms to the $\mathrm{C}-\mathrm{Cl}-\mathrm{Si}$ planes are 68.8 and $71.6 \mathrm{pm}$, suggesting that the bond between the two silicon atoms is not a complete double bond. The X-ray single-crystal structural bond parameters and the valency of the two carbene carbon atoms and of the two silicon atoms indicate an interesting bonding situation.

A comparison of compound $\mathrm{A}^{11}$ with compound 2 clearly shows that both $\mathrm{C}-\mathrm{Si}$ bonds as well as the $\mathrm{Si}-\mathrm{Si}$ bond in $\mathbf{2}$ are significantly shorter (Scheme 2). An explanation for the

Scheme 2. Bonding Situation and Comparison of Bond Lengths of Compound $\mathrm{A}^{11}$ with Compound 2

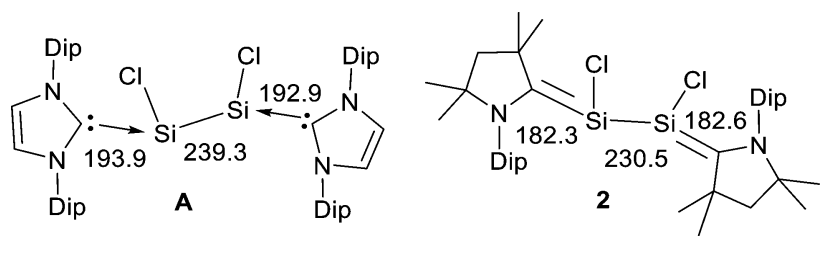

different structures can be given in terms of the bonding situations of the molecules which are sketched in Scheme 2 . Molecule $\mathbf{A}$ has $\mathrm{NHC} \rightarrow(\mathrm{SiCl})_{2} \leftarrow \mathrm{NHC}$ donor-acceptor bonds while 2 possesses cAAC- $(\mathrm{SiCl})_{2}-\mathrm{cAAC}$ electron-sharing bonds. A similar change in the bonding situation was recently reported for $\mathrm{NHC} \rightarrow \mathrm{SiCl}_{2}$ and $\mathrm{cAAC}-\mathrm{SiCl}_{2}-\mathrm{cAAC}$. $^{\text {a }}$

The $\mathrm{C}-\mathrm{Si}-\mathrm{Si}-\mathrm{C}$ fragment in $\mathbf{2}$ could be compared with a distorted trans-2,3-disila-1,3-butadiene which carries terminal amino groups. This interpretation agrees with the available experimental and theoretical data. The $\mathrm{Si}-\mathrm{Si}$ distance in 2 $(230.5 \mathrm{pm})$ concurs very well with the calculated value for trans-2,3,-disila-1,3-butadiene $(229.9 \mathrm{pm})^{15}$ The $\pi$-conjugation in $\mathbf{2}$ is not fully effective because the $\mathrm{C}-\mathrm{Si}-\mathrm{Si}-\mathrm{C}$ fragment is not planar but has a dihedral angle of $163.6^{\circ}$ while the $\mathrm{Cl}-\mathrm{Si}-$ $\mathrm{Si}-\mathrm{Cl}$ moiety has a torsion angle of $43.3^{\circ}$. This explains why the $\mathrm{C}-\mathrm{Si}$ distance in $2(182.3 / 182.6 \mathrm{pm})$ is significantly longer than in trans-2,3,-disila-1,3-butadiene $(172.7 \mathrm{pm}) .{ }^{15}$ The distortion from $\pi$-conjugation comes clearly to the fore when the shapes of the two highest lying occupied orbitals are 
considered (Figure 2). The HOMO shows some $\mathrm{C}-\mathrm{Si}$ and $\mathrm{Si}-$ Si $\pi$ conjugation, but the HOMO-1 (Figure 2) denotes two
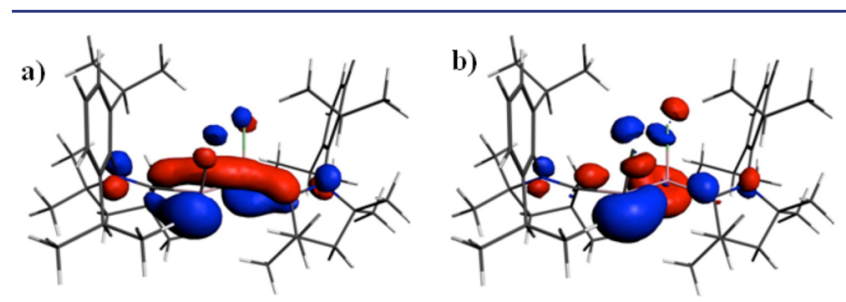

Figure 2. (a) HOMO and (b) HOMO-1 of compound 2.

weakly bonding electrons at the silicon atoms. Thus, while compound 2 may be considered as substituted trans-2,3-disila1,3-butadiene, it becomes obvious that the substituents exert a strong distortion on the $\pi$-conjugation in the parent system. ${ }^{16}$

Quantum chemical calculations at the BP86/TZVPP level predict a singlet ground state for 2 which is $27.9 \mathrm{kcal} / \mathrm{mol}$ lower than the triplet state and $54.8 \mathrm{kcal} / \mathrm{mol}$ lower than the quintet state. The caption of Figure 1 provides that the optimized bond distances and angles are in very good agreement with the experiment. The silicon atoms exhibit a pyramidal coordination where the $\mathrm{Cl}-\mathrm{Si}-\mathrm{Si}-\mathrm{Cl}$ dihedral angle (calcd $45.9^{\circ}$, expt $43.3^{\circ}$ ) is even more twisted than the $\mathrm{C}-\mathrm{Si}-\mathrm{Si}-\mathrm{C}$ angle (calcd $165.0^{\circ}$, expt $163.6^{\circ}$ ).

In conclusion, we have synthesized $\left(\mathrm{Me}_{2}-\mathrm{cAAC}\right)_{2}\left(\mathrm{Si}_{2} \mathrm{Cl}_{2}\right)$ (2) through a controlled reduction of the zwitterionic adduct $\mathrm{Me}_{2}$-cAAC: $\mathrm{SiCl}_{4}$ (1) with $\mathrm{KC}_{8}$ in THF. Compound 2 can be regarded as a 1,4-diamino-2,3-disila-1,3-butadiene derivative. Theoretical calculation revealed that the twisted conformation about the $\mathrm{C}-\mathrm{Si}-\mathrm{Si}-\mathrm{C}$ fragment, which is possibly caused by steric interactions of the bulky substituents, leads to longer silicon-carbon bond lengths in $2 .{ }^{17}$ To the best of our knowledge the preparation of such species has not been reported before.

Previously the $\mathrm{NHC}: \mathrm{SiCl}_{4}$ adduct was reduced to bis-silylene ( $\mathrm{NHC}: \mathrm{Si}(:) \mathrm{Cl})_{2}$ (A) with $\mathrm{KC}_{8}$. The cAAC analogue of $\mathbf{A}$ can be better described as 2,3-disila-1,3-butadiene derivative (2). It possesses a singlet ground state and is isolable and stable between $0^{\circ}$ and $-32{ }^{\circ} \mathrm{C}$ for at least 3 months, but after one week 2 slowly loses its color if stored at room temperature. The bond between the silicon and the carbene carbon atom changes its nature from a coordinate bond in $\mathbf{1}$ to a covalent electronsharing double bond in 2 .

Synthesis of Compound $\left(\mathrm{Me}_{2}-\mathrm{CAAC}\right)_{2}\left(\mathrm{Si}_{2} \mathrm{Cl}_{2}\right)$ (2). The 1:3 molar solid mixture of $\mathrm{Me}_{2}-\mathrm{CAAC} \mathrm{SiCl}_{4}$ (1) $(3.3 \mathrm{mmol})$ and $\mathrm{KC}_{8}(10.0 \mathrm{mmol})$ and THF $(80 \mathrm{~mL})$ were separately cooled to $-78{ }^{\circ} \mathrm{C}$, and then THF was added through a cannula. The reaction mixture was stirred at $-78{ }^{\circ} \mathrm{C}$ for $30 \mathrm{~min}$ to produce a light green solution and black residue of graphite. Then the reaction solution was slowly warmed to room temperature and stirred for $2-3 \mathrm{~h}$. During this period, the color of the solution changed from light green to red. The black residue was separated by filtration, dried under vacuum, and extracted with $n$-hexane $(80 \mathrm{~mL})$. The volume of $n$-hexane solution was decreased to $10-15 \mathrm{~mL}$. Transparent needles of 2 were formed after 1 day either at room temperature or at $0{ }^{\circ} \mathrm{C}$ in a refrigerator. Compound 2 was separated by filtration and dried under vacuum. $\mathrm{C}, \mathrm{H}$, and $\mathrm{N}$ analysis found (calcd) for $\mathrm{C}_{40} \mathrm{H}_{62} \mathrm{Cl}_{2} \mathrm{~N}_{2} \mathrm{Si}_{2} ; \mathrm{C} 68.52$ (68.83), H 8.85 (8.95), N 4.08 (4.01). Decomposes above $109{ }^{\circ} \mathrm{C}$. NMR data of 2 are given in the Supporting Information. UV-visible bands: 615, 526, 438, 349, and $254 \mathrm{~nm} .{ }^{1} \mathrm{H}$ NMR (500.133 MHz, $\left.\mathrm{C}_{6} \mathrm{D}_{6}, 298 \mathrm{~K}, \delta \mathrm{ppm}\right)$ : 7.09-7.03 (m, 3H, Har $), 3.11\left(\mathrm{~m}, 2 \mathrm{H}, \mathrm{CHMe}_{2}\right), 1.903(\mathrm{~s}, 6 \mathrm{H}$, $\mathrm{NCMe}_{2}$ ), 1.69 (s, 2H, CH $\left.6 \mathrm{H}, \mathrm{CHMe}_{2}\right), 1.01$ (s, $\left.6 \mathrm{H}, \mathrm{CMe}_{2}\right) .{ }^{13} \mathrm{C} \mathrm{NMR}(\delta \mathrm{ppm}): 148.6$, 129.2, 128.3, 124.7, 71.9, 55.8, 50.6, 33.1, 31.8, 30.9, 30.7, 29.0, 27.6, 24.6, 22.9. ${ }^{29} \mathrm{Si}$ NMR $(\delta \mathrm{ppm}):+25.62$. Compound 5 should not be dried under vacuum at room temperature for long since it slowly decomposes and slowly loses its color.

\section{ASSOCIATED CONTENT}

\section{S Supporting Information}

Synthesis, UV, crystallographic table, and theoretical details. This information is available free of charge via the Internet at http://pubs.acs.org. CCDC 928147 contains the supplementary crystallographic data of compound 2 . These data can be obtained free of charge from The Cambridge Crystallographic Data Centre via www.ccdc.cam.ac.uk/data_request/cif.

\section{AUTHOR INFORMATION}

\section{Corresponding Author}

hroesky@gwdg.de

\section{Notes}

The authors declare no competing financial interest.

\section{ACKNOWLEDGMENTS}

Dedicated to Professor C. N. R. Rao on the occasion of his 80th birthday. H.W.R. thanks the Deutsche Forschungsgemeinschaft (DFG RO 224/60-I) for financial support. We are thankful to the reviewers for their valuable comments.

\section{REFERENCES}

(1) (a) Sekiguchi, A.; Kingo, R.; Ichinohe, M. Science 2004, 305, 1755-1757. (b) Wiberg, N.; Niedermeyer, W.; Fischer, G.; Nöth, H.; Suter, M. Eur. J. Inorg. Chem. 2002, 1066-1070. (c) Sasamori, T.; Hironaka, K.; Sugiyama, Y.; Takaki, N.; Nagase, S.; Hosoi, Y.; Furukawa, Y.; Tokitoh, N. J. Am. Chem. Soc. 2008, 130, 13856-13857.

(2) Gau, D.; Kato, T.; Saffon-Merceron, N.; De Cozar, A.; Cossio, F. P.; Baceiredo, A. Angew. Chem. 2010, 122, 6735-6738; Angew. Chem., Int. Ed. 2010, 49, 6585-6588.

(3) Karni, M.; Apeloig, Y.; Schröder, D.; Zummack, W.; Rabezana, R.; Schwarz, H. Angew. Chem. 1999, 111, 343-347; Angew. Chem., Int. Ed. 1999, 38, 331-335.

(4) (a) Brook, A. G.; Abdesaken, R.; Gutekunst, B.; Gutekunst, G.; Kallury, R. K. J. Chem. Soc., Chem. Commun. 1981, 191-192. (b) West, B.; Fink, M. J.; Michl, J. Science 1981, 14, 1343-1344. (c) Fischer, R. C.; Power, P. P. Chem. Rev. 2010, 110, 3877-3923.

(5) Weidenbruch, M.; Willms, S.; Saak, W.; Henkel, G. Angew. Chem. 1997, 109, 2612-2613; Angew. Chem., Int. Ed. 1997, 36, 2503-2504.

(6) Ghadwal, R. S.; Azhakar, R.; Roesky, H. W. Acc. Chem. Res. 2013, 44, 444-456.

(7) (a) Mondal, K. C.; Roesky, H. W.; Schwarzer, M. C.; Frenking, G.; Tkach, I.; Wolf, H.; Kratzert, D.; Herbst-Irmer, R.; Niepötter, B.; Stalke, D. Angew. Chem., Int. Ed. 2013, 52, 1801-1805; Angew. Chem. 2013, 125, 1845-1850. (b) Mondal, K. C.; Roesky, H. W.; Schwarzer, M. C.; Frenking, G.; Niepötter, B.; Wolf, H.; Herbst-Irmer, R.; Stalke, D. Angew. Chem., Int. Ed. 2013, 52, 2963-2967; Angew. Chem. 2013, 125, 3036-3040.

(8) (a) Martin, D.; Soleilhavoup, M.; Bertrand, G. Chem. Sci. 2011, 2, 389-399. (b) Martin, D.; Melaimi, M.; Soleilhavoup, M.; Bertrand, G. Organometallics 2011, 30, 5304-5313.

(9) (a) Wang, Y.; Xie, Y.; Wie, P.; King, R. B.; Schaefer, H. F., III; Schleyer, P. v. R.; Robinson, G. J. Am. Chem. Soc. 2008, 130, 1497014971. (b) Back, O.; Kuchenbeiser, G.; Donnadieu, B.; Bertrand, G. Angew. Chem., Int. Ed. 2009, 48, 5530-5533; Angew. Chem. 2009, 121, $5638-5641$. 
(10) Mondal, K. C.; Roesky, H. W.; Stückl, A. C.; Ihret, F.; Kaim, W.; Dittrich, B.; Maity, B.; Koley, D. Angew. Chem., Int. Ed. 2013, DOI: 10.1002 /anie.201300668.

(11) Wang, Y.; Xie, Y.; Wei, P.; King, R. B.; Schaefer, H. F., III; Schleyer, P. v. R.; Robinson, G. H. Science 2008, 321, 1069-1071.

(12) Martin, C. D.; Soleilhavoup, M.; Bertrand, G. Chem. Sci. 2013, 4, 3020-3030.

(13) Lee, V. Y.; Sekiguchi, A. Organometallic Compounds of LowCoordinate $\mathrm{Si}, \mathrm{Ge}, \mathrm{Sn}$ and $\mathrm{Pb}$ : From Phantom Species to Stable Compounds; Wiley: Chichester, 2010; Chapter 5.

(14) See ref 7a for a detailed description of the bonding interactions.

(15) Fernández, I.; Frenking, G. Chem.-Eur. J. 2006, 12, 36173629. The value for the $\mathrm{C}-\mathrm{Si}$ distance is found in the Supporting Information.

(16) The distortion is mainly caused by electronic effects rather than steric interactions. Geometry optimization at BP86/TZVPP of $\left(\mathrm{NH}_{2}\right)$ $\mathrm{HC}=\mathrm{Si}(\mathrm{Cl})-\mathrm{Si}(\mathrm{Cl})=\mathrm{CH}\left(\mathrm{NH}_{2}\right)$ show that the equilibrium geometry has strongly pyramidal coordinated silicon atoms with a dihedral angle $\mathrm{Cl}-\mathrm{Si}-\mathrm{Si}-\mathrm{Cl}$ of $36.6^{\circ}$ while the parent systems $\mathrm{H}_{2} \mathrm{C}=\mathrm{Si}(\mathrm{Cl})-$ $\mathrm{Si}(\mathrm{Cl})=\mathrm{CH}_{2}$ is planar.

(17) Calculations with less bulky amino substituents gave also strongly twisted conformations which suggest that the twisting of the structure occurs due to electronic interactions. Holzmann, N. Ph.D. Thesis, Marburg, 2013. 